\title{
PERAN MUSEUM ARMA DAN MUSEUM BURUNG BALI DALAM PEMBERDAYAAN BUDAYA DAN MASYARAKAT LOKAL
}

\author{
I Made Mardika \\ Universitas Warmadewa \\ dikamar73@gmail.com
}

\begin{abstract}
ABSTRAK
Artikel ini bertujuan mengidentifikasi peran Museum Arma dan Museum Burung Bali dalam pemberdayaan budaya dan masyarakat local serta menginterpretasikan maknanya. Metode penelitian bersifat kualitatif dengan pendekatan kajian budaya. Pengumpulan data dengan teknik observasi, wawancara mendalam dan dokumentasi, analisis data dengan metode induktif. Hasil penelitian menunjukkan Museum Arma dan Museum Burung Bali berperan dalam pemberdayaan budaya dan masyarakat local. Museum Arma melakukan dengan model pengelolaan museum secara terintegrasi dan mewujudkan museum hidup. Museum Burung Bali melakukan dengan mempekerjakan seniman local untuk membuat koleksi maupun barang cinderamata dan pementasan tari-tarian tradisional Bali. Proses ini dapat dimaknai sebagai respon budaya local terhadap budaya global, strategi dekonstruktif yakni peningkatan budaya local melalui pembalikan dari luar ke dalam, dan kapitalisasi budaya local yang eksploitatif dan dominatif. Simpulan penelitian bahwa $\mathrm{Mu}-$ seum Arma dan Museum Burung Bali berperan dalam pemberdayaan budaya dan masyarakat lokal melalui strategi tertentu yang merefleksikan makna respon budaya, peningkatan budaya lokal, dan kapitalisasi budaya.
\end{abstract}

Kata kunci: pemberdayaan budaya lokal, masyarakat lokal, peran museum

\begin{abstract}
[Title: The Roles of Museum Arma and Museum Burung Bali in Empowering the Culture and Local Society] This article aims to identify roles of Museum Arma and Museum Burung Bali in empowering the culture and local society and to interpret its meaning. The research model is qualitative research. The data collection were done by observation technique, deep interview and documentation, and the data analysis were done inductively. The result shows two ways in empowering the culture and local society. Museum Arma empowers them by museum integrated management model and living museum. Museum Burung Bali empowers them by employing local artist to make collection, souvenirs and traditional Balinese dance performances. The process can be interpreted as local cultural response towards global culture, the deconstructive strategy towards inversion from outside to inside, and the capitalization towards local culture. The conclusion is both museums have roles in empowering the culture and local society towards certain strategies reflexing the meaning of cultural response, local culture improvement, and cultural capitalization.
\end{abstract}

Keywords: empowering the local culture, local society, the role of museum 
Vol. 2, No. 1, Januari 2018, 80

Available Online at https://ejournal.warmadewa.ac.id/index.php/kulturistik

DOI: dx.doi.org/10.22225/kulturistik.2.1.678

\section{PENDAHULUAN}

Sangat menarik untuk dicermati adanya fenomena yang berkembang belakangan ini di Ubud khususnya, dan di Bali pada umumnya. Semarak perkembangan industri pariwisata telah berdampak kepada kegairahan masyarakat Bali untuk melakukan konservasi budaya melalui pendirian museum. Museummuseum baru terus didirikan oleh kalangan swasta, bermunculan, bagaikan jamur di musim hujan. Dari pengamatan lapangan yang dilakukan oleh penulis, dapat dicatat bahwa di Ubud saja ada sepuluh museum, terdiri atas 6 museum yang telah lama berdiri (meliputi Museum Puri Lukisan, Museum Neka, Museum Rudana, Museum Blanco, Museum 'Pendet' Widya Kusuma dan Museum Arma) serta 4 museum swasta yang belakangan ini didirikan, yaitu Museum Alon, Museum Topeng, Museum Burung Bali dan Museum patung Garuda 'Adaguna'. Jumlah ini belum termasuk belasan museum yang ada di berbagai kabupaten di Bali. Jika kecendrungan ini terus berkembang boleh jadi nantinya sebutan untuk Bali bukan hanya Pulau Seribu Pura, tetapi bertambah lagi menjadi "Pulau Seribu Museum".

Diantara museum-museum tersebut Museum Arma dan Museum Burung Bali menarik perhatian penulis. Sebagai salah satu museum lukisan Museum Arma (Agung Rai Musuem of Art) sangat berbeda dibanding museum lukisan lainnya yang ada di Ubud. Perbedaannya tampak dari sistem pengelolaan, jenis museum dan partisipasi masyarakat setempat. Ditinjau dari sistem pengelolaan Museum Arma dikelola secara terpadu yang mengintegrasikan museum dengan sarana penunjang pariwisata lainnya seperti hotel, restoran, dan tempat hiburan. Dilihat dari jenis museum, Museum Arma digolongkan sebagai museum hidup. Museum ini berupaya menyajikan praktik-praktik kehidupan masyarakat Bali yang terdapat pada koleksi lukisannya. Untuk menunjang praktik-praktik kehidupan budaya tersebut partisipasi masyarakat sekitar museum banyak dilibatkan (Mardika, 2010: 255-287). Tiga hal yang konsisten dilakukan dalam pengelolaan museum menjadi pertimbangan bagi penulis memilih Museum Arma sebagai objek kajian tulisan ini.

Museum Burung Bali berlokasi di Banjar Tengkulak Kelod Desa Kemenuh Kecamatan Sukawati Kabupaten Gianyar (terletak sekitar 2 KM sebelah timur Museum Arma). Ada tiga hal pula yang membuat museum ini spesial dibanding museum yang lain. Pertama, Museum Burung Bali didirikan oleh orang asing, seorang mantan peneliti kehidupan satwa (Zoolog) yang berkebangsaan Amerika. Kedua, koleksi museum bukan burung-burung sungguhan seperti halnya di Bali Bird Park maupun di Bali Zoopark, melainkan aneka patung burung yang dibuat oleh para perajin lokal. Ketiga, dan yang paling penting adalah peran museum ini dalam rangka memberdayakan budaya \& masyarakat lokal. Tiga alasan ini menjadi pertimbangan mengapa Museum Burung Bali juga dijadikan objek kajian dalam tulisan ini.

Harus dipahami bahwa peran Museum Arma dan Museum Burung Bali dalam konteks pemberdayaan masyarakat lokal berada pada setting pariwisata sebagai domain budaya global. Oleh karena itu, museum tidak boleh lagi dilihat secara konvesional yakni semata-mata lembaga nirlaba yang hanya mengemban misi edukatif cultural. Lebih dari pada itu, museum bisa saja dikategorikan sebagai jenis industri kreatif yang jika dikelola dengan baik mampu memberikan keuntungan secara finansial (Mardika, 2011: 111; Sutaarga, 1991: 14-15; Ashworth, 1997). 
Percaturan global dengan intensitas aksi dan reaksi budaya yang demikian tinggi membutuhkan perspektif baru dalam menelaah dimensi museum sebagai fokus kajian. Pada titik ini kedua museum tersebut hendaknya ditempatkan dalam koridor Manajemen Sumberdaya Budaya (MSDB). MSDB merekomendasikan pengelolaan sumberdaya kultural untuk dimanfaatkan secara efektif demi kesejahteraan masyarakat dan menjamin kelestarian sumberdaya tersebut secara berkelanjutan (Dradjat, 1999: 3-5). Implikasi dari paradigma ini membawa konsekuensi pada cara pandang 'memperlakukan' museum yakni perlu dibedah dengan teori-teori kritis yang posmordenis. Demikianlah persoalan tentang peran museum dalam pemberdayaan masyarakat lokal dapat dipandang sebagai 'mazhab Arkeologi Kritis' yang mencoba menerapkan teori-teori sosial kritis secara eklektik seperti teori glokalisasi, teori komodifikasi budaya, dan teori dekonstruksi (Mundardjito, 2007: 1-9).

Dengan kajian kritis ini diharapkan dapat diidentifikasi bentuk-bentuk pemberdayaan masyarakat lokal oleh museum dan sekaligus menemukan makna yang tersirat dari relasi yang terbangun antara museum dengan masyarakat setempat. Sasaran akhir yang ingin dicapai adalah agar dapat dipetik manfaat teoritis maupun praktis dari penelaahan dua museum ini. Manfaat secara teoritis adalah berupaya menawarkan perspektif baru dalam penelaahan jagad kearkeologian di Indonesia khususnya Museologi. Manfaat secara praktis terutama lebih dialamatkan kepada pemerintah dalam rangka menyusun kebijakan terkait dengan permuseuman, dan kepada masyarakat sebagai bahan informasi ilmiah tentang kecendrungan perkembangan museum di era global.

\section{METODE}

Penelitian ini dirancang menggunakan metode kualitatif. Penelitian kualitatif berupaya mengumpulkan data deskriptif berupa kata-kata baik lisan maupun tulisan dan prilaku yang dapat diamati berdasarkan setting alamiah (natural setting) (Moleong, 1989: 3). Pengumpulan data dilaksanakan dengan teknik observasi partisipasi, wawancara mendalam, dan teknik dokumentasi. Penentuan informan dilakukan dengan teknik purposive sampling yang menyasar pengelola Museum, dan masyarakat lokal yang terkait dengan penyelenggaraan museum. Ketiga teknik pengumpulan data tersebut saling melengkapi dan mendukung satu sama lain dalam konteks triangulasi data.

Penelitian ini menggunakan pendekatan Kajian Budaya yang memadukan secara ekliktik perspektif Arkeologi (analisis terhadap budaya materi, fungsi, dan kontekstualitasnya) dengan paradigma Cultural Studies yakni metode dekonstruksi, teori glokalisasi, dan komodifikasi budaya (Barker, 2005 : 36; Ratna, $2010: 290-293$ ).

Model analisis data yang dilakukan dalam penelitian ini adalah analisa induktif dengan metode deskriptif kualitatif atau kualitatif interpretatif (Ratna, 2010: 305-310). Proses analisis deskriptif mencakup tiga alur kegiatan yang saling terkait yaitu: (1) reduksi data, (2) penyajian data, dan (3) penyimpulan atau verifikasi (Miles, 1992 : 17-19). Reduksi data merupakan suatu proses memilah, menyederhanakan, mengabsahkan, dan mentransformasikan data mentah yang diperoleh di lapangan. Penyajian data dilakukan dengan menemukan pola-pola hubungan yang bermakna serta memberi kemungkinan adanya penarikan kesimpulan. Setelah itu dilakukan penyimpulan, yakni suatu upaya menarik simpulan berdasarkan reduksi data dan penyajian data yang telah dilakukan 


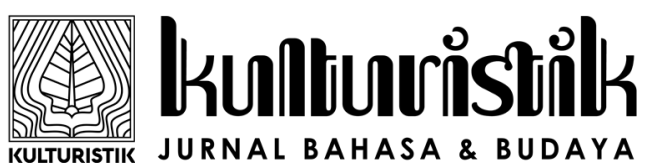

Vol. 2, No. 1, Januari 2018, 82

Available Online at https://ejournal.warmadewa.ac.id/index.php/kulturistik DOI: dx.doi.org/10.22225/kulturistik.2.1.678

sebelumnya. Penyajian hasil analisis data disusun dalam bentuk informal dan formal, yakni dalam bentuk uraian naratif yang ditunjang dengan bentuk gambar peta, foto, dan tabel.

\section{PEMBAHASAN}

Museum Arma: Pemberdayaan Budaya dan Masyarakat Lokal

Museum Arma terletak di jalan Pengosekan, Desa Peliatan, Ubud - Bali. Lokasi museum sangat strategis karena berada pada tiga titik singgung desa pekraman yaiu Desa Padang Tegal, Pengosekan, dan Desa Peliatan. Ketiga desa ini dikenal sebagai pusat perkampungan seniman baik seni lukis, seni patung, dan seni tari (Pujani, 1988: 22). Museum Arma adalah museum seni lukis yang didirikan oleh Anak Agung Gede Rai 18 tahun yang lalu, tepatnya pada tanggal 9 Juni 1996 saat diresmikan oleh Menteri P\&K Prof. Dr. Ingg. Wardiman Djojo Negoro. Pada awalnya Agung Rai adalah seorang pedagang asongan (pedagang acung, bahasa Bali) yang kemudian sukses menjadi pengusaha seni lukis dengan mendirikan galeri Agung Rai. Trajektori perjalanan hidupnya hingga berhasil mengembangkan Museum bertaraf internasional termuat dalam buku biografi berjudul Gung Rai: Kisah Sebuah Museum (Couteau \& Wisatsana, 2013).

Koleksi Museum Arma merupakan lukisan terpilih maha karya seniman pribumi dan seniman asing yang menggambarkan kebudayaan Bali. Tema-tema budaya Bali yang dituangkan dalam lukisan tersebut oleh Arma diaktualisasikan secara nyata sehingga membentuk 'museum hidup' (living museum), yakni museum yang mengkontekstualisasikan lukisan dengan praktik kehidupan sehari-hari seperti seni pertunjukan, tradisi ritual, lingkungan alam pedesaan, pengelolaan sawah secara tradisional, termasuk kuliner khas Bali. Misalnya, koleksi lukisan berjudul The Dance Lesson karya I Gusti Nyoman Lempad direalisasikan dengan program belajar menari bagi pengunjung museum (seperti gambar di bawah ini)
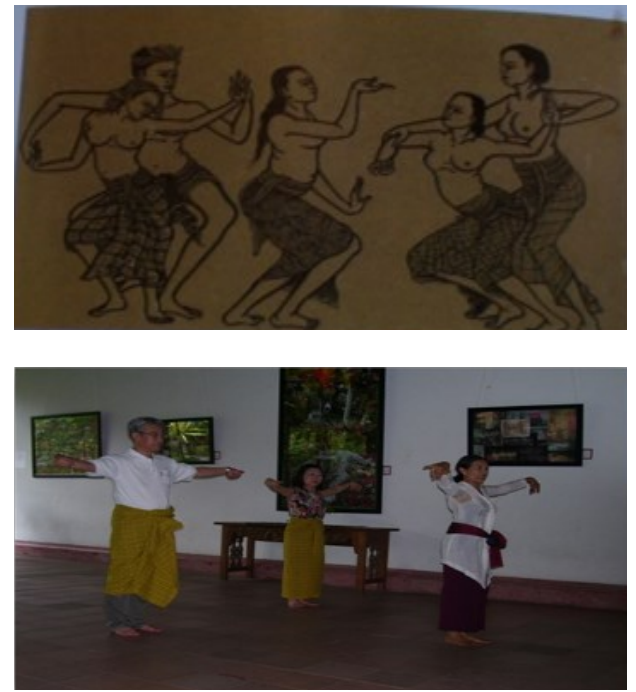

Gambar 1. Koleksi lukisan Museum Arma "The Dance Lesson" karya I Gusti Nyoman Lempad (atas) dan pengunjung museum 'wisatawan Jepang' belajar menari (bawah). (Sumber: repro dok. Koleksi Arma \& dok. Pribadi) 
Untuk mendukung visi museum sebagai pusat budaya, kawasan Arma seluas 6 hektar dirancang dengan sistem pengelolaan integratif (model subsidi silang) yang memadukan museum sebagai lembaga nonprofit dengan usaha-usaha penunjang seperti resort, restaurant, Cafe Arma, Cofee Shop, open stage untuk pertunjukan seni, dan balai pertemuan. Tentu tata kelola museum model subsidi silang membutuhkan sistem manajemen modern, artinya baik manajemen koleksi, finansial, SDM, dan manajemen pemasaran mesti dikelola secara profesional (Mardika, 2010: 264-282)

Dengan pola penerapan strategi manajemen modern Museum Arma berusaha mencapai dua tujuan sekaligus, yaitu mendapatkan "citra" dan prestise di tingkat internasional di satu sisi, dan memberdayakan budaya serta masyarakat lokal di sisi lain. Di kancah global museum Arma telah mengupayakan terobosan sebagai berikut: (1) publikasi pada media-media top dunia seperti CNN, dan NHK Jepang, (2) menyelenggarakan even-even berskala internasional seperti pameran seni, seni pertunjukan, konggres / seminar internasional, (3) mendatangkan ahli-ahli konservator dunia, (4) penerbitan buku oleh peneliti asing, dan (5) menjalin kemitraan dengan biro perjalanan wisata yang memasarkan tentang keunikan budaya Bali. Pentingnya menjalin hubungan dengan media asing diyatakan oleh Agung Rai, sebagai berikut:

"ada perbedaan yang tajam antara situasi pers di Indonesia dengan media massa asing. Wartawan asing sangat obyektif dan peka melihat apa yang layak untuk diangkat di media massa. Mereka melihat kualitas, dinamika, manajemen dan keseriusan kita untuk mngelolanya. Kalau sudah masuk media akan dibaca dan dikritisi, atau sebagai bahan rujukan jika mereka berkunjung ke Bali. Inilah posisi media massa asing bagi keberadaan museum" (wawancara, 11 Juni 2014).

Guna menarik minat wisatawan manca negara berkunjung ke Museum Arma pengelola museum menyuguhkan unsur budaya lokal Bali yang khas. Budaya lokal dijadikan identitas, dan dikemas menjadi produk unggulan museum. Penentuan koleksi museum misalnya, disamping memakai kriteria umum, konsep taksu dijadikan syarat utama dalam pemilihan koleksi. Konsep taksu tak terpaku pada segi estetis, pewarnaan dan gaya lukisan, akan tetapi lebih kepada unsur dalam 'aura' yang dipancarkan suatu lukisan. Karya metaksu yang dijadikan syarat koleksi menurut Agung Rai "apabila lukisan itu memancarkan suatu 'aura' yang diilhami spirit tertentu. Seniman secara spontanitas tergerak oleh kekuatan 'magis' untuk berkarya, sehingga menghasilkan lukisan penuh ilham dan spektakuler". Taksu adalah suatu kekuatan dari dalam yang dapat dirasakan, tidak dengan sengaja dicari atau didapat melalui studi (Lenon, 1998: 6). Taksu dianggap sebagai inspirasi dewa, bakat, semacam kharisma yang diberikan para dewa kepada seniman (Mantra, 1993: 15-16)

Pemberdayaan budaya lokal tampak pula dalam rancang bangun museum Arma. Pendirian kawasan Arma mengacu pada tata letak bangunan rumah tradisional Bali 'Asta Kosala Kosali' yang didasarkan pada falsafah Tri Hita Karana. Kompleks bangunan Arma dibagi menjadi tiga bagian 'tri mandala' terdiri atas: palemahan (bangunan luar/penunjang), pawongan (bangunan utama), dan parahyangan (pura / tempat suci). Pada bagian palemahan terdapat tiga pintu masuk yakni pintu selatan, pintu timur, dan pintu barat. Pintu selatan merupakan pintu utama (main intrance) menuju museum, sedangkan pintu barat untuk masuk 
Vol. 2, No. 1, Januari 2018, 84

Available Online at https://ejournal.warmadewa.ac.id/index.php/kulturistik

DOI: dx.doi.org/10.22225/kulturistik.2.1.678

ke Cafe Arma dan pintu timur akses terdekat ke hotel / resort \& restaurant. Bangunan utama museum terdiri atas tiga gedung utama, yaitu: bale daja, bale dauh, dan bale delod. Dua gedung utama, yakni bale daja dan bale dauh dipakai untuk tempat pameran tetap, sedangkan bale delod dipakai ruang perkantoran dan pameran temporal. Bangunan untuk tempat suci (pura) terdapat di arah timur laut museum.

Pengembangan kawasan Arma sekarang ini berupaya menjaga lingkungan sekitar museum (palemahan) agar tetap lestari. Konservasi alam dimaksudkan agar para pengunjung museum dapat menikmati panorama alam pedesaan, hamparan sawah berteras, lengkap dengan suasana keseharian petani yang setia mempertahankan pengerjaan sawah secara tradisional. Untuk menjaga keajegan budaya lokal di bidang tradisi bertani museum memberikan semacam subsidi dana kepada para petani di sekitar lahan museum sebagai apresasi atas peran sertannya ikut menjaga alam dan budaya tradisional Bali.

Strategi kemitraan yang dijalankan Museum Arma dengan para petani setempat hanyalah salah satu wujud pemberdayaan museum kepada masyarakat lokal. Model pemberdayaan masyarakat setempat lainnya berupa pemanfaatan tenaga kerja lokal, pengembangan seni kepada generasi muda dan kelompok tua, serta pelaksanaan aksi-aksi sosial. Di bidang tenaga kerja, Museum Arma lebih memprioritaskan tenaga kerja yang berasal dari lingkungan sekitar museum untuk direkrut sebagai karyawan Arma group. Para seniman pemula yang berbakat diberikan kesempatan untuk memamerkan karyanya di museum secara gratis. Museum Arma juga menyelenggarakan 13 paket program pelatihan dan bengkel kerja kebudayaan Bali kepada publik museum. Paket program yang ditawarkan meliputi: Balinese painting, Balinese music gamelan, wood carving, Balinese dance \& theatre, Shadow puppetry, Tradisional Healing, Balinese Cooking, Hinduism in Bali, dan History of Bali. Instruktur yang melaksanakan pelatihan seni budaya ini adalah para seniman sepuh atau tokoh-tokoh masyarakat di sekitar museum yang dianggap berpengalaman dan memiliki ketrampilan di bidangnya. Tokoh-tokoh seniman sepuh juga dilibatkan sebagai pembina / pelatih seni untuk mengajarkan anak-anak yang tergabung dalam sanggar Arma.

Sanggar Arma sesungguhnya merupakan wadah yang disiapkan Arma untuk pelestarian dan pengembangan seni. Museum Arma menyediakan pendidikan seni secara gratis kepada generasi muda khususnya anak-anak sekolah untuk mengembangkan minat dan bakatnya di bidang seni tari, tabuh, dan seni lukis. Selain sanggar anak-anak, juga terdapat sanggar werdha yang diperuntukan bagi kelompok dewasa / tua. Aktivitas sehari-hari sanggar anak-anak dan sanggar werdha Arma menjadi 'daya hidup' dan sekaligus tontonan yang menarik bagi pengunjung museum. Sanggar Arma juga cukup sering mengadakan pagelaran seni baik di lingkup lokal, nasional, maupun sebagai duta seni di manca negara. Pentas seni sangat penting artinya bagi anak-anak yang tergabung dalam sanggar Arma karena disamping memperoleh pengalaman berharga, mereka juga diberikan 'uang saku' setelah pertunjukan berakhir.

Dalam mendekatkan keberadaan museum dengan masyarakat sekitar, $\mathrm{Mu}-$ seum Arma senantiasa mengadakan aksi sosial. Aksi sosial yang dimaksud berupa pemberian punia (donasi) dan mengadakan pentas seni di pura-pura yang ada di sekitar museum. Penyampaian sumbangan berupa uang dan pagelaran seni, biasanya dilaksanakan oleh Arma tiap enam bulan pada saat pura-pura tersebut melangsungkan upacara perayaan 'odalan'. 
Vol. 2, No. 1, Januari 2018, 85

Available Online at https://ejournal.warmadewa.ac.id/index.php/kulturistik DOI: dx.doi.org/10.22225/kulturistik.2.1.678

\section{Cara Museum Burung Bali Memberdayakan Masyarakat Lokal}

Lokasi Museum Burung Bali terletak pada areal persawahan di Banjar Tengkulak Kelod, Desa Kemenuh, Kecamatan Sukawati, Kabupaten Gianyar. Museum ini didirikan oleh seorang ahli Zoologi berkebangsaan Amerika bernama Frank William. Sebelum menggagas pendirian museum, ia adalah seorang peneliti satwa yang secara intensif mengadakan penelitian tentang kehidupan burung-burung yang hidup di Bali. Museum ini dibangun sejak tahun 2008 dan dibuka secara resmi pada hari Sabtu, 8 Januari 2011, kemudian dipublikasikan pada harian Balipost tanggal 2 Januari 2013. Tujuan pendirian museum adalah untuk melestarikan dan memamerkan koleksi ukiran burung yang seakan-akan hidup sesuai diorama aslinya, sekaligus bertujuan mendidik masyarakat mengetahui peran burung-burung Bali dalam sistem lingkungan.

Koleksi Museum Burung Bali tergolong sangat unik, karena berupa aneka jenis patung burung (replika burung) yang mewakili 360 rumpun burung yang hidup di Bali. Species burung tersebut diklasifikasi menjadi 10 kelompok berdasarkan dioramanya. Ada kelompok burung laut, burung air, burung buas, burung berkaki panjang, burung penyanyi, burung malam, dan kelompok lainnya (seperti gambar 2 di bawah ini).

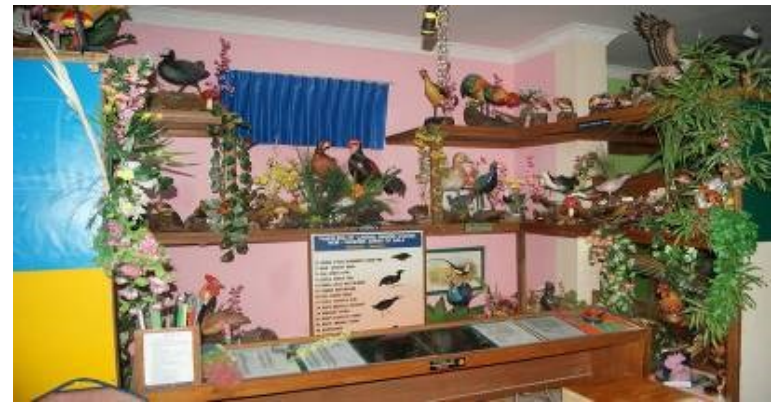

Gambar 2. Beberapa koleksi patung burung di Museum Burung Bali Sumber: wisatadewata/article/wisata/museum-bali-bird.

Museum Burung Bali berdiri di atas areal tanah seluas 4 are, terdiri atas bangunan dua lantai. Fasilitas yang disediakan museum meliputi: (1) daerah resepsi, 'stan' daerah untuk burung yang tidak sebangsa dengan burung gereja, (3) 'stan' bagi daerah burung sebangsa burung gereja, (4) diorama habitat burung bangau, (5) buku tentang burung untuk anak-anak, (6) ruang tayang (proyektor digital sony), (7) disket DVD tentang burung, (8) buku-buku yang dibuat museum, (9) ruang tayang kecil (lantai I), (10) ruang proyektor lebih besar (lantai II), (11) Perpustakaan burung, (12) daerah studi perpustakaan, (13) ruang gamelan dan angklung, (14) panggung untuk melihat pemandangan sawah, dan (15) dua toilet.

Tenaga kerja yang mengelola museum ini terdiri atas: pemilik museum (owner), dan dua orang staf pegawai lokal yakni I Wayan Ramu dan Nyoman Sarma. Selain itu, dalam proses pembuatan koleksi patung burung dikerjakan 12 orang perajin patung kayu dari banjar Tengkulak Kelod. Semua model patung dibuat dengan sangat detil, baik dari segi bentuk, warna, dan ukurannya. Tentang ketrampilan perajin disebutkan dalam brosur museum:

"para pengukir kayu itu mempunyai bakat yang luar biasa, kebanyakan dari mereka telah mengukir sejak kecil. Burung-burung yang diukir mereka 
Vol. 2, No. 1, Januari 2018, 86

Available Online at https://ejournal.warmadewa.ac.id/index.php/kulturistik

DOI: dx.doi.org/10.22225/kulturistik.2.1.678

seolah-olah siap untuk terbang. Burung-burung di museum diukir sesuai dengan besar, warna, dan kebiasaan. Ukiran itu merupakan karya yang indah sekali dan alat pendidikan yang berharga"

Patung-patung burung koleksi Museum Burung Bali dapat dipandang sebagai suatu karya seni yang merupakan hasil dari proses perencanaan dan pengkonstruksian bentuk-bentuk tri matra dengan sifat-sifat sebagai berikut: (a) menggambarkan obyek sebenarnya atau khayal, (b) menyajikan sebuah rancangan bentuk tiga dimensi, (c) menyugestikan berbagai jenis gagasan, perasaan, dan pengalaman lain (Suwandi, 1999). Untuk mengekspresikan ide seniman sampai dengan terwujudnya suatu karya seni patung tersebut dilalui dengan proses kejiwaan yang didasari atas pengalaman intelektual, daya imajinasi, dan daya kreatifitas.

Dalam proses penciptaan patung faktor internal dan faktor eksternal pematung memegang peranan penting. Faktor internal menyangkut bakat dan pengalaman seniman dalam teknik dan apresiasi terhadap produk patung yang dihasilkan. Sedangkan, faktor ekternal menyangkut pengalaman dan lingkungan seperti kepercayaan serta aspek spiritual. Sudah tentu faktor internal pematung memberi manfaat dalam penciptaan patung burung sebagai bentuk tiruan burung yang sesungguhnya karena memang pematung yang membuat seni patung burung tersebut telah memiliki ketrampilan dan pengalaman membuat jenis-jenis patung burung. Faktor ekternal tidaklah begitu merisaukan pematung karena replika burung yang hendak diwujudkan merupakan burung-burung yang hidup di lingkungannya (Bali). Hanya saja ada beberapa burung yang telah punah, sehingga sedikit menyulitkan pematung dalam mengekspresikan wujud dan keakurasian ukuran serta proporsinya.

Hal seperti ini diakui oleh salah seorang perajin yang penulis wawancarai. I Ketut Nadi (50 tahun) menyatakan, bahwa: "mengerjakan bentuk patung burung agar menyerupai wujud aslinya memerlukan ketelitian, kecermatan, dan ketrampilan yang baik. Ketidaksesuaian bentuk, warna, maupun proporsinya berarti kegagalan dalam mewujudkan patung burung sebagai koleksi museum. Dan, itu harus diulang kembali dari awal" (wawancara tanggal 8 januari 2013). Meskipun dikatakan relatif rumit oleh pematung, dari pihak pemesan tampaknya merasa puas dan amat mengapresiasi karya yang dihasilkan (lihat kutipan brosur di atas). Bentuk penghargaan ini secara tidak langsung merepresentasikan keunggulan para pengrajin patung di Desa Tengkulak khususnya pengrajin patung burung di Banjar Tengkulak Kelod yang diakui memiliki identitas lokal dalam menciptakan karya seni patung burung. Penentuan 12 pematung dari Banjar Tengkulak Kelod yang dipilih sebagai pemahat patung burung termasuk dalam kreteria tersebut.

Pemberdayaan terhadap para pematung lokal juga dilakukan museum apa bila ada pengunjung yang berminat untuk memiliki tiruan koleksi museum sebagai benda cinderamata. Museum mempercayakan pembuatan duplikat patung burung kepada perajin setempat. Dalam hal ini Museum Burung Bali bertindak sebagai perantara antara konsumen (pengunjung museum) dengan perajin lokal. Setelah pesanan selesai dibuat oleh perajin kemudian duplikat koleksi diserahkan kepada museum, dan pihak museumlah yang menyampaikan pesanan patung tersebut kepada konsumen. Dengan memberikan kepercayaan membuat pesanan patung burung pihak museum secara tidak langsung berperan pula mempromosi- 
kan karya perajin lokal di tingkat internasional. Hal ini dibuktikan dengan cukup banyak tersebarnya sentra kerajinan patung burung di Desa PekramanTengkulak. Bahkan sampai sekarang motif patung burung dan bebek menjadi icon produk kerajinan patung dari Desa Tengkulak.

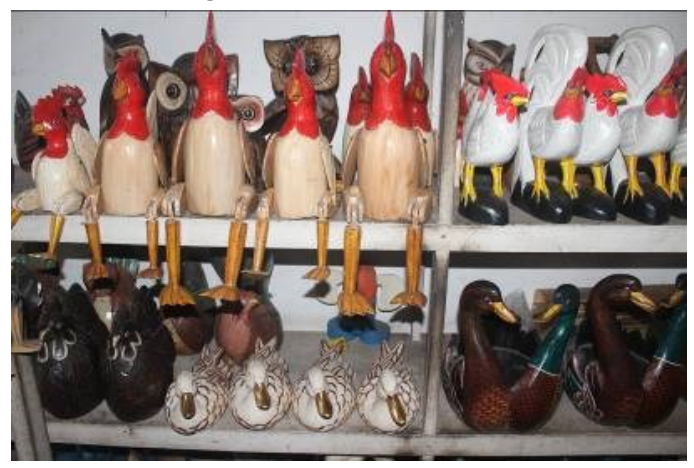

Gambar 3. Aneka motif patung burung dan bebek karya perajin Tengkulak sebagai icon kerajinan patung di Desa Tengkulak

(sumber: dokumen pribadi, 2016)

Selain pemberdayaan kepada pematung lokal, keterlibatan masyarakat setempat dilakukan oleh Museum Burung Bali melalui pagelaran seni. Salah satu paket program yang di ditawarkan museum kepada pengunjung adalah atraksi tarian Bali yang mengisahkan tetang kehidupan burung seperti tari Manuk Rawa, tari Belibis, dan tari Garuda Wisnu Kencana. Untuk penyelenggarakan pagelaran seni tari Bali ini museum mempercayakan kepada penari-penari yang berasal dari penduduk di sekitar museum, termasuk para penabuh yang mengiringi tarian tersebut.

\section{Museum: Ajang Pergulatan Identitas Lokal VS Kapitalisasi Budaya}

Memperhatikan peran yang dimainkan Museum Arma dan Museum Burung Bali dalam pemberdayaan masyarakat lokal tidak berlebihan jika dikatakan sebagai 'model' pengelolaan museum yang berbasis komunitas (community based management). Pola-pola pengelolaan museum mengacu kepada MSDB yang bertumpu pada dimensi kebudayaan lokal dan partisipasi penduduk setempat. Masyarakat lokal tidak hanya diposisikan sebagai objek, akan tetapi diikutsertakan sebagai subjek yang berhak atas apresiasi serta diberikan manfaat nyata.

Pemberdayaan masyarakat lokal oleh museum bila dicermati dengan perspektif kritis bisa menunjukan beragam makna. Jika fenomena globalisasi dipahami sebagai interaksi budaya yang dinamis dan berpengaruh timbal balik, maka dalam proses tersebut, terjadi proses globalisasi dan glokalisasi budaya sekaligus. Dalam keadaan demikian, budaya lokal merespon budaya global dengan memanfaatkan peluang yang ada untuk membangkitkan dan menguatkan kembali unsur-unsur budaya lokal (Triono, 1996: 14-16). Pada kasus Museum Arma dan Museum Burung Bali kecendrungan global seperti gaya hidup konsumerisme yang ingin menikmati budaya lokal yang autentik ditangkap sebagai peluang oleh pengelola museum dengan cara memberdayakan budaya lokal sebagai ciri indentitas museum. Model pengelolaan museum secara professional dan terintegrasi dengan menyuguhkan unsur-unsur budaya lokal secara kreatif-inovatif sesuai pula dengan jargon "global perspektif, local action". Menjadi global tidak 
Vol. 2, No. 1, Januari 2018, 88

Available Online at https://ejournal.warmadewa.ac.id/index.php/kulturistik

DOI: dx.doi.org/10.22225/kulturistik.2.1.678

harus mengejar hingga ke dunia barat, melakukan aksi di tingkat lokal yang mampu mempengaruhi dunia 'internasional' adalah bagian dari usaha aktor pribumi yang kreatif.

Proses ini bisa pula dimaknai paralel dengan skema metode dokonstruksi. Metode dekonstruksi berupaya membongkar wacana-wacana kemapanan untuk ditata kembali guna melahirkan makna baru (Santoso, 2007: 252-253). Strategi pembongkaran dilakukan dengan membalik oposisi biner yakni dominasi budaya barat (global) yang dipandang superior mesti dirobohkan, digantikan oleh posisi budaya lokal. Budaya lokal yang dianggap 'inferior' diangkat ke permukaan untuk menghadapi universalisme budaya modernis barat (Barker, 2005: 252-253). Strategi dekonstruksi ini sekaligus beranjak dari 'luar' menuju ke 'dalam'. Ketika budaya lokal dijadikan daya pesona museum untuk menarik minat wisatawan asing, diharapkan timbul umpan balik kepada masyarakat pribumi selaku pendukung budaya tersebut dalam mencintai dan mejaga keajegan budaya miliknya. Cinta kepada budaya sendiri bukan semata-mata harus dimulai dari 'orang dalam', tetapi bisa juga beranjak dari 'orang luar' untuk ditularkan dan diperkuat secara bersama-sama kepada 'orang dalam'. Inilah esensi metode dekonstruksi yang dimainkan dua museum tersebut.

Tampaknya harus disadari, bahwa di era globalisasi sekarang ini pergulatan antara budaya lokal dengan budaya global belum berakhir. Pada saat agen-agen lokal memanfaatkan domain budaya sebagai komoditas untuk ditawarkan ke pasar, saat itu pula budaya telah tergelincir ke dalam proses komodifikasi (Mulyanto, 2012: 20-27). Proses komodifikasi menyangkut praktik-praktik produksi, distribusi, hingga penerimaannya oleh konsumen. Dengan kata lain, komodifikasi berarti unsur budaya yang bukan komoditi, dikemas sedemikian rupa menjadi komoditas (dipaket-paket sebagai daya tarik wisata) untuk menghasilkan keuntungan. Proses ini sarat logika kapitalisasi dengan keutungan materi (kuasa uang) sebagai panglimanya (Suyanto, 2013: 175).

Boleh jadi kesediaan, dukungan, dan partisipasi masyarakat lokal amat berimpitan dengan unsur keuntungan ekonomi yang diperolehnya. Lebih-lebih produksi komoditas dalam ranah budaya bukan sekadar hubungan benda, namun lebih merupakan hubungan sosial. Hubungan sosial dimaksud disini adalah relasi yang melibatkan antara kelas pemilik modal dengan kelas masyarakat 'bawah' yang bersifat tidak setara, cenderung dominatif dan eksploitatif (Hasan, 2011: 187 -190). Dominatif artinya pola hubungan yang terjadi antara museum sebagai pemilik modal 'kapital' cenderung menguasai masyarakat lokal yang hanya mengandalkan modal budaya. Bukan hanya dikuasai, boleh jadi masyarakat setempat dieksploitasi demi memuaskan hasrat wisatawan akan budaya lokal yang autentik. Dalam situasi seperti ini, sesungguhnya masyarakat setempat terhegemoni (dikuasai secara halus dengan persetujuan) oleh Museum. Museum meraup keuntungan besar atas jerih payah dan partisipasi penduduk lokal yang tetap saja menjadi pelengkap penderita karena memperoleh konpensasi dana yang tak seberapa. Penduduk lokal tetap marginal di bawah kendali kapitalisasi budaya global yang menempel pada sosok industri nirlaba yakni museum (Mardika, 2011: 108-111).

Ketiga perspektif di atas hanyalah penelisikan awal yang mesti ditindaklanjuti dengan kajian yang lebih rinci dan mendalam. Pergerakan bandul yang melibatkan pergulatan identintitas lokal dengan kapitalisme budaya global mesti terus disikapi dengan model kajian-kajian kritis, sehingga Arkeologi tetap dapat bersuara pada tataran budaya kontemporer, khususnya kepada kelompok yang 
terpinggirkan.

\section{KESIMPULAN}

Peran Museum dalam pemberdayaan budaya dan masyarakat lokal dapat dilihat sebagai perwujudan MSDB. Museum Arma dan Museum Burung Bali adalah dua museum yang membuktikan perannya dalam pemberdayaan budaya dan masyarakat lokal. Pengelolaan Museum Arma sebagai living museum dengan model subsidi silang menunjukan peran ganda, baik dalam pelestarian budaya Bali maupun dalam pemberdayaan masyarakat setempat. Pelestarian budaya dilakukan Museum Arma dengan mengemas unsur-unsur budaya lokal yang khas sebagai ciri identitas museum. Pemberdayaan masyarakat setempat ditempuh $\mathrm{Mu}-$ seum Arma dengan cara-cara: (1) menjalin kemitraan dengan para petani di sekitar lahan museum, (2) memanfaatkan tenaga kerja lokal sebagai karyawan dan seniman Werdha sebagai instruktur seni, (3) membentuk sanggar seni anak-anak dan kelompok tua untuk pentas di luar negeri, (4) aksi sosial yaitu memberikan donasi (punia) dan pentas seni (ngayah) di pura-pura di sekitar museum.

Museum Burung Bali juga berperan baik dalam pemberdayaan budaya Bali maupun pelibatan masyarakat setempat. Pemberdayaan budaya lokal dilakukan museum dalam wujud mempercayakan pembuatan koleksi museum kepada perajin setempat, dan pementasan tarian tradisional Bali yang bertema kehidupan burung. Pemanfaatan pematung lokal, penari dan penabuh dalam pementasan tari bertema burung di museum dapat dipandang sebagai wujud peran Museum Burung Bali dalam pelibatan masyarakat lokal.

Peran museum dalam pemberdayaan budaya dan masyarakat lokal paling tidak mengandung tiga makna penting. Pertama, dapat dilihat sebagai respon budaya lokal kepada budaya global. Dinamika budaya global ditanggapi oleh museum dengan mengemas budaya lokal yang autentik sehingga membentuk apa yang disebut oleh kalangan teoritisi posmordernis sebagai glokalisasi budaya. Kedua, sebagai usaha menaikan status budaya lokal ke kancah internasional. Strategi yang ditempuh bersifat dekonstruktif - membalik oposisi biner - yakni beranjak dari pemusatan unsur budaya Bali agar diapresiasi oleh 'orang luar' selanjutnya menuju kepada 'orang dalam'. Ketiga, peran yang dimainkan museum kepada budaya \& masyarakat lokal tidak luput dari wacana kapitalisasi budaya. Dalam hal ini peran museum berada pada bingkai kapitalis 'pengusaha' yang memperoleh keuntungan dengan memanfaatkan budaya dan masyarakat setempat, sehingga unsur 'lokal' masih tetap berada pada posisi pinggiran.

\section{SARAN}

Memperhatikan demikian pentingnya peran museum baik dalam pelestarian budaya dan pemberdayaan masyarakat lokal, tampaknya pemerintah perlu lebih memperhatikan nasib museum di satu sisi dan melakukan pengawasan di sisi lain. Pemerintah selayaknya memberikan apresiasi kepada museum yang telah secara nyata melibatkan peran masyarakat local sekaligus meningkatkan kesejahteraannya. Menjadi kewajiban pula bagi pemerintah untuk mengadakan evaluasi dan pengawasan kepada museum-museum yang demikian tersebar di Bali. Dibutuhkan adanya kebijakan yang konprehensif dalam rangka menumbuhkan iklim yang kondusif tentang tata kelola permuseuman yang demikian menjamur di Bali.

Penting pula untuk dicatat bahwa permasalahan museum di Indonesia dan termasuk Bali sangatlah kompleks dan tidak akan pernah habis untuk ditelaah. 
Partisipasi stakeholder terutama pihak pemerintah, swasta, dan masyarakat penting menyatukan barisan duduk bersama-sama guna memperbincangkan keberadaan museum. Inilah bagian dari tugas 'arkeologi kritis' melakukan apresiasi dan pembelaan kepada kelompok yang lemah. Harapan ke depan semakin banyak 'cendikia' yang mengarahkan pandangan ke bidang ini.

\section{DAFTAR PUSTAKA}

Ashworth, G. J. (1997). Elements of Planning and Managing Heritage Sites. In Tourism and Heritage Management (pp. 165-169). Yogyakarta: Gajah mada University Press.

Barker, C. (2005). Cultural studies: teori dan praktek. Yogyakarta: PT. Bentang Pustaka.

Couteau, J., \& Wisatsana, W. (2013). Gung Rai: kisah sebuah museum. Jakarta.

Dradjat, H. U. (1999). Manajemen sumber daya budaya" dalam buletin cagar budaya: pelestarian benda cagar budaya dan kepribadian bangsa (I). Jakarta: Direktorat Perlindungan dan Pembinaan Peninggalan Sejarah dan Purbakala Jakarta.

Hasan, S. S. (2011). Pengantar cultural studies: sejarah, pendekatan konseptual \& isu menuju studi budaya kapitalisme lanjut. Yogyakarta: Jalasutra.

Lenon, K. (1998). Museum seni Agung Rai (Agung Rai Museum of Art), UbudBali: sebuah usulan aplikasi manajemen umum.

Mantra, I. B. (1993). Masalah sosial budaya dan modernisasi. Denpasar: PT. Upada Sastra.

Mardika, I. M. (2010). "'Membaca' Pengelolaan Museum Arma Sebagai Manajemen Sumberdaya Budaya". Forum Arkeologi, XXIII No., 255-287.

Mardika, I. M. (2011). Representasi Karya Seni Patung Koleksi Museum Burung Bali di Desa Tengkulak (Pergulatan Identitas Lokal dan Kuasa Kapital). Sadhana Sastra Jurnal Sastra Dan Budaya, Vol. 23 no, 101-111.

Miles, M. \& A. M. H. (1992). A nalisis Data Kualitatif. Jakarta: UI Press.

Moleong, L. (1989). Metodologi Penelitian Kualitatif. Bandung: Remaja Rosda Karya.

Mulyanto, D. (2012). Genealogi Kapital: Antropologi dan Ekonomi Politik Pranata Eksploitasi Kapitalisik. Yogyakarta: Resist Book.

Mundardjito. (2007). Paradigma dalam Arkeologi Maritim. Jurnal Wacana FIB UI, Vol. 9 no., 1-9.

Pujani, L. P. K. (1988). Peran Agen Asing dalam Pertumbuhan Seni Lukis di Desa Ubud. Denpasar.

Ratna, N. K. (2010). Metodologi Kajian Budaya dan Ilmu Sosial Humaniora pada Umumnya. Yogyakarta: Pustaka Pelajar.

Santoso, H. (2007). Metode Dekonstruksi Derrida: Kritik Atas Metafisika dan Epistemologi Modern. In Seri Pemikiran Tokoh Epistemologi Kiri (pp. 247 -260). Yogyakarta: AR-RUZZ Media.

Sutaarga, M. A. (1991). "Peran Museum, Kaitannya dengan Kajian dan Penyajian Sejarah" Museografia Jilid XX No. 2 Depdikbud.

Suwandi, I. W. (1999). Inovasi Ida Bagus Tilem Dalam Seni Patung Bali Modern. Program Pascasarjana Universitas Udayana, Denpasar.

Suyanto, B. (2013). Sosiologi Ekonomi Kapitalisme dan konsumsi di Era Masyarakat Post-Modernisme. Jakarta: Kencana Prenada Media Group.

Triono, L. (1996). Globalisasi Modernitas dan Krisis Negara Bangsa: Tantangan 


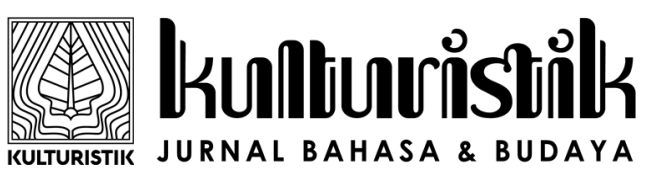

Vol. 2, No. 1, Januari 2018, 91

Available Online at https://ejournal.warmadewa.ac.id/index.php/kulturistik

DOI: dx.doi.org/10.22225/kulturistik.2.1.678

Integarsi Nasional dalam Konteks Global. Analysis CSIS Tahun XXV No.2. 